\title{
Effects of timing of glyphosate application on jack pine, black spruce, and white spruce plantations in northern Manitoba ${ }^{1}$
}

\author{
by Songling Fu², ${ }^{3}$, Han Y.H. Chen², 4 , F. Wayne Bell ${ }^{5}$, Mahadev Sharma ${ }^{5}$, Jeff R. Delaney ${ }^{6}$ and Glenn Peterson ${ }^{6}$
}

\begin{abstract}
Deferring conifer release treatments is sometimes necessary, but its effects on crop tree performance are not well understood. We investigated the effects of deferring glyphosate applications on jack pine (Pinus banksiana Lamb.), black spruce (Picea mariana [Mill.] BSP), and white spruce (Picea glauca [Moench.] Voss.) plantations established on a dry site with moderate competition and a moist site with heavier competition in The Pas, northern Manitoba. At each site, experimental treatments included no herbicide and one glyphosate (formulated as Vision ${ }^{\oplus}$ ) at $1.42 \mathrm{~kg}$ acid equivalent glyphosate ha ${ }^{-1}$ application between one and five years after planting with three replications. Survival, root collar diameter, and height of the three conifers were repeatedly measured for ten consecutive years following planting. Survival of the three conifers was not affected by glyphosate application. For all the three species, root collar diameter and stand volume of crop trees increased significantly in glyphosate-treated plots, compared to control plots. Varying the timing of glyphosate application between year 1 and 5 resulted in a similar conifer dimensions. Glyphosate application significantly improved height growth of black spruce and marginally white spruce, but not jack pine. On these sites, glyphosate reduced the cover of woody species, but grass, forbs and shrubs rapidly captured the newly available growing space. A two variable regression analysis revealed that grass cover negatively affected stand volume of all three conifer species. Cover of tall shrub, forbs, and interaction of cover and height of tall shrubs were the next most important variables to explain jack pine, black spruce, and white spruce volume growth, respectively.
\end{abstract}

Key words: vegetation management, forest herbicides, survival, growth, stand volume, long-term repeated measurements

\section{RÉSUMÉ}

Le report des traitements de dégagement des coniferes est parfois nécessaire, mais ses effets sur la performance des arbres à récolter ne sont pas bien connus. Nous avons étudié les effets du report des applications glyphosate dans le cas de plantations de pin gris (Pinus banksiana Lamb.), d'épinette noire (Picea mariana [Mill.] BSP) et d'épinette blanche (Picea glauca [Moench.] Voss.) établies sur station sèche ayant un niveau modéré de compétition et sur station humide avec une compétition plus accentuée dans la région de The Pas dans le nord du Manitoba. Pour chaque station, les traitements expérimentaux comprenaient un témoin et une application de $1,42 \mathrm{~kg} \mathrm{ha}^{-1} \mathrm{~d}^{\prime}$ agent équivalent de glyphosate (selon la formule Vision ${ }^{\circledR}$ ) entre un et cinq ans après plantation, le tout selon trois reproductions. La survie, le diamètre de la racine au collet et le volume du peuplement constitué d'arbres à récolter ont été mesurés pendant dix années consécutives après la plantation. La survie des trois espèces de coniferes n'a pas été affectée par l'application de glyphosate. Pour les trois espèces, le diamètre de la racine au collet et le volume du peuplement constitué d'arbres à récolter ont augmenté significativement dans les parcelles traitées au glyphosate, comparativement aux parcelles témoins. La variation dans le moment de l'application de glyphosate entre l'an 1 et l'an 5 a eu pour conséquence des dimensions semblables chez les coniferes. L'application de glyphosate a amélioré de façon significative la croissance en hauteur des épinettes noires et de façon marginale celle des épinettes blanches, mais pas celle des pins gris. Sur ces stations, le glyphosate a réduit le couvert des espèces ligneuses, mais les plantes graminées, les plantes herbacées et les arbustes ont rapidement pris possession de l'espace de croissance nouvellement disponible. Une analyse de régression à deux variables a révélé que le couvert herbacé a affecté négativement le volume du peuplement dans le cas des trois espèces de coniferres. Le couvert des grands arbustes et des plantes herbacées, ainsi que l'interaction du couvert et de la hauteur des grands arbustes ont été les variables les plus importantes en second lieu pour expliquer la croissance en volume respectivement du pin gris, de l'épinette noire et de l'épinette blanche.

Mots clés : contrôle de la végétation, herbicides forestiers, survie, croissance, volume du peuplement, mesures répétées à long terme

\footnotetext{
${ }^{1}$ Paper presented at the Forestry and Industrial Working Group of the Canadian Weed Science Society, November 28-29, 2006, Victoria, BC

- "Today's Silviculture: Tomorrow's Forest"

${ }^{2}$ Faculty of Forestry and the Forest Environment, Lakehead University, 955 Oliver Rd, Thunder Bay, Ontario P7B 5E1.

${ }^{3}$ College of Forestry and Gardening, Anhui Agricultural University, 130 Changiiang Rd., Hefei, China 230036.

${ }^{4}$ Corresponding author. E-mail address: han.chen@lakeheadu.ca

${ }^{5}$ Ontario Forest Research Institute, Ontario Ministry of Natural Resources, 1235 Queen Street East, Sault Ste. Marie, Ontario P6A 2 E5.

${ }^{6}$ Manitoba Conservation Forestry Branch, 200 Saulteaux Crescent, Winnipeg, Manitoba R3J 3W3.
} 


\section{Introduction}

Clearcutting in boreal forests typically favours the development of opportunistic, fast-growing herbaceous and woody species, which capture available resources at the expense of conifer seedlings (Munson et al. 1993, Sutherland and Foreman 2000). Clearcutting of mixedwood forest types on nutrient-rich, mesic soils often promotes vegetative reproduction of deciduous hardwoods such as trembling aspen (Populus tremuloides Michx.), balsam poplar (Populus balsamifera L.), and white birch (Betula papyrifera Marsh.). Once the hardwoods are controlled through the use of herbicides or motor-manual cutting, grasses and forbs can quickly colonize the available growing space (Bell et al. 1997). Competition from grasses, forbs, shrubs and deciduous hardwoods reduces the survival and growth of conifer seedlings (Balandier et al. 2006).

Competition control typically improves crop tree growth in northern temperate and southern boreal forests and can be accomplished in a number of ways including the use of herbicides (Walstad and Kuch 1987, Munson et al. 1995, Thompson and Pitt 2003, Chen et al. 2006, Fu et al. 2007). Aerial application of herbicides, such as glyphosate (N-[phosphonomethyl] glycine), has been widely used in North America to control competing vegetation with the objective of increasing conifer growth (Walstad and Kuch 1987). Wagner et al. (2006) reported gains for several boreal conifers ranging from 0.3 and $8.2 \mathrm{~m}^{3} \mathrm{~h}^{-1}$ for white spruce (four studies), $6.2 \mathrm{~m}^{3} \mathrm{~h}^{-1}$ for black spruce (one study), and $13.3 \mathrm{~m}^{3} \mathrm{~h}^{-1}$ for jack pine (one study) based on 10- to 12-year post-treatment measurements. These results are based on experimental units that were treated annually for up to five years with glyphosate and may represent biological maximums for the species studied. Gains following operational applications of glyphosate are unlikely to be equivalent to those that have been reported in the literature. Glyphosate is typically applied only once during a rotation, mostly in the second post-plant growing season but applications have been deferred to the third or even fifth post-plant season for political, financial, or technical reasons.

The objective of this study was to examine the effects of operational timing of glyphosate applications on jack pine, black spruce, and white spruce plantations in northern Manitoba. We specifically addressed two questions: (1) When is the optimum time to release the conifer crop trees from competition that includes herbaceous plants, woody shrubs, and hardwood trees in northern boreal forests? We used crop tree survival and the growth parameters root collar diameter and height to evaluate crop tree performance at the individual-tree level and stand volume of crop trees at the stand level. (2) Do different conifer species respond differently to year of application? We compared survival and growth performance of the three tree species based on ten years of repeated measurements on two plantations in northern Manitoba.

\section{Materials and Methods \\ Study area and sites}

The study sites were located near The Pas, Manitoba, with the latitude $53^{\circ} 58^{\prime} \mathrm{N}$, longitude $101^{\circ} 6^{\prime} \mathrm{W}$, and average elevation $270.40 \mathrm{~m}$. The Pas has a mean annual temperature of $0.1^{\circ} \mathrm{C}$, and mean precipitation is $443 \mathrm{~mm}$, of which $324 \mathrm{~mm}$ falls as rain. Average July and August temperatures are $17.7^{\circ} \mathrm{C}$ and $16.5^{\circ} \mathrm{C}$, respectively, with corresponding mean monthly precipitation of $65 \mathrm{~mm}$ and $63 \mathrm{~mm}$ (Environment Canada
2005). Two plantations were established within the Manitoba Lowland Section (B.15) of the Boreal Forest Region (Rowe 1972), respectively.

\section{Goose Lake research site}

The site was located on a generally flat area north of Goose Lake, Manitoba, which is about $40 \mathrm{~km}$ north of The Pas. The soil is clay without coarse fragments and strongly calcareous. The site is subject to prolonged spring flooding from snow melt and soil moisture regime is fresh to moist during the growing season, i.e., moist site. The pre-harvest stands were conifer-dominated mixedwoods, consisting of black spruce, trembling aspen, balsam poplar (Populus balsamifera L.), white spruce, jack pine, in decreasing order of importance based on stand volume; trembling aspen and balsam poplar contributed approximately $30 \%$ of the stand basal area. According to Sims et al. (1997) the predominant pre-harvest stands would be classified as a black spruce mixedwood/herb rich (V19). It was clearcut with conventional full-tree harvesting during winter 1988 and mechanically site prepared with a Ripper Tooth Plow in 1989. The Plow was pulled by a tracked Caterpillar tractor, which pushed aside logging debris and created a continuous furrow in which to plant. A Slash Rake was mounted on the front of the tractor and was used to push aside and pile fallen and relatively small standing hardwood trees. Seedlings were planted in the cleared area with no further soil disturbance other than kicking off the duff layer by planters.

\section{Root Lake research site}

The site is located about $20 \mathrm{~km}$ northwest of The Pas. The gently rolling loamy soils in this area contain moderate coarse fragments. The site is subject to spring flooding as a result of frozen soils retaining water from melted snow, but it is generally dry during the growing season, i.e., dry site. According to Sims et al. (1997) the predominant pre-harvest stands would be classified as a black spruce/feather moss (V33). The site was clearcut with conventional full-tree harvesting in the spring and summer of 1986 and 1987 and mechanically prepared in summer and fall of 1986 and 1989. The Root Lake site was site prepared with a Bracke Patch Scarifier, pulled behind a rubber-tired skidder, to create two rows of intermittent planting patches spaced approximately $2 \mathrm{~m}$ apart.

\section{Experiment}

A completely randomized block design with two blocks (study sites), six treatments and three replications was used. Within each of the two blocks, 18 treatment plots $(90 \mathrm{~m} \times 170 \mathrm{~m})$ were established and randomly assigned to one of the six proposed treatments: no glyphosate, aerial chemical release with Vision $^{\mathrm{R}}$ at a rate of $4 \mathrm{~L} \mathrm{ha}^{-1}(1.42 \mathrm{~kg}$ acid equivalent [a.e.] glyphosate $\mathrm{ha}^{-1}$ ) applied one, two, three, four, or five years after the conifers were planted. The location of treatment plots was planned to avoid excessively wet or dry microsites.

Buffers surrounding rectangular treatment plots were established to prevent influence from adjacent residual stands and by off-target deposits of glyphosate. Sample plots were located a sufficient distance from the edge of the treatment block to ensure complete treatment coverage. Each sample plot was subdivided into three subplots that were randomly selected to be planted with black spruce, jack pine, or white spruce in late spring 1990. Four hundred container seedlings grown from local seed were planted in each subplot at a 2-m 
spacing (Delaney 1992). The average height and root calliper diameter were $15 \mathrm{~cm}$ and $2.1 \mathrm{~mm}$ for black spruce, $10 \mathrm{~cm}$ and $2.3 \mathrm{~mm}$ for jack pine, and $16 \mathrm{~cm}$ and $2.3 \mathrm{~mm}$ for white spruce, respectively.

Glyphosate applications were conducted in mid- August between 1991 and 1995 and spray cards were used to confirm the delivery and droplet size of glyphosate within each the treatment block. A Cessna Ag Truck was used to apply the $4 \mathrm{~L}$ $\mathrm{ha}^{-1}$ of glyphosate mixed with $45 \mathrm{~L} \mathrm{ha}^{-1}$ of water at an average speed of approximately $175 \mathrm{~km} / \mathrm{h}$. The delivery system employed D10-46 nozzles and operated at a pressure of 21 P.S.I. Six passes were made over each treatment block with each swath being approximately $20 \mathrm{~m}$ wide.

\section{Conifer field measurements and analysis}

Within each subplot, a randomly located $100-\mathrm{m}^{2}$ sample plot was established to provide 25 planted conifer seedlings for measurements. All 25 seedlings within each sample plot were measured annually in August from 1990 to 1999. During each measurement, survival, root collar diameter $(\mathrm{cm})$, and height (m) were assessed.

Survival was calculated for each plot at each measurement year as a ratio of surviving trees to total number of trees planted. Individual tree stem volume $(V)$, assumed to be conical (sensu Pitt et al. 2004), was calculated from root collar diameter and height using the follow function (Eq. 1):

$$
V=\frac{1}{3} \pi\left(\frac{R C D}{2}\right)^{2} \times H
$$

where $R C D=$ root collar diameter $(\mathrm{cm})$ and $H=$ tree height $(\mathrm{cm})$. All individual tree volumes were summed to subplot level and then scaled to per hectare to provide stand volume estimates.

For each planted species, we tested the effects of timing of treatment application using the following General Linear Model (Eq. 2) (Hicks 1993):

$[2]$

$$
\begin{aligned}
& Y_{i j \text { Im }}=\mu+\overbrace{S_{i}+T_{j}+S_{i j}+P_{k(i j)}}^{\text {betweten mbjocti }} \\
& \text { within maljects } \\
& +\mathrm{Y}_{1}+\mathrm{SY}_{\mathrm{i}}+\mathrm{TY}_{\mathrm{jl}}+\mathrm{ST} \mathrm{Y}_{\mathrm{ijl}}+\varepsilon_{\operatorname{mil}(i \bar{j})}
\end{aligned}
$$

where $\mathrm{Y}_{\mathrm{ijkl}}=$ the dependent variable of interest including survival, mean RCD, height, and stand volume of crop trees, respectively; $\mu=$ overall mean; $S_{i}=$ sites $(i=1,2) ; T_{j}=$ timing of glyphosate application $(\mathrm{j}=1,2,3,4,5,6), P_{k(\mathrm{ij})}=$ experimental plot within each site $(\mathrm{k}=1,2, \ldots 18)$ and the error term for effects between subjects; $Y_{l}=$ year of measurement $(l$ $=1,2, . .10)$, and $e_{m l k(i)}$ is the random error within subjects (Hicks 1993).

To simplify analysis, we also tested if herbicide timing resulted in different responses of crop trees by using the tenth year data only. The following model was used (Eq. 3):

$$
\text { [3] } \quad Y_{j, j]}=\mu+S_{j}+T_{f}+\varepsilon_{k(\xi)}
$$

where $\mathrm{Y}_{\mathrm{ijk},}, \mu, S_{i}$ and $T_{j}$ are same as described in Eq. 2. Tukey's post hoc multiple comparisons were performed when effects were significant $(\alpha=0.05)$. Normality and homogeneity of variances were confirmed following the procedure described in Neter et al. (1996). Stand volume was log transformed to meet the homogeneity assumption. Since Eq. 2 and Eq. 3 resulted in similar trends, we reported only the statistical results from Eq. 3. All statistical tests were performed using SYSTAT 10 (Systat Software Inc., San Jose, California).

\section{Non-crop vegetation field measurements}

Visual estimates of foliar cover projected onto ground level of individual fern, grass, forb, shrub and tree species were estimated to the nearest $5 \%$ by sampling four systematically located, crop-centred, 4- $\mathrm{m}^{2}$ (1.13-m radius) non-overlapping circular quadrates per treatment plot. At the same time competitor height was measured to the nearest $5 \mathrm{~cm}$ using a height pole or a yard stick for competitors taller or shorter than $2 \mathrm{~m}$, respectively. Assessments were made annually in August from 1990 to 1999. Average cover by broad vegetation category was calculated for each treatment through three steps. First, individual species were categorized into one of seven broad classes (i.e., fern, grass, forb, low shrub, tall shrub, hardwood, and conifer). Second, the cover of each species within a category was summed for each $4-\mathrm{m}^{2}$ sample plot. Average heights were determined in the same manner. Third, sample plot totals were summed by treatment and averaged. Since cover is additive, total sums may exceed $100 \%$.

\section{Regression analysis of gross total volume with non-crop vegetation} The effect of competing vegetation on volume growth of crop trees was examined using regression analyses. Stand volume of crop trees of the tenth year measurements (1999) was regressed against cover, height, and cover $\times$ height interactions of each competing vegetation category (i.e., fern, grass, forb, low shrub, tall shrub, hardwood, and softwood) using backward stepwise regression.

\section{Results}

\section{Conifer responses}

Survival did not differ significantly with glyphosate treatment, but did with site (Table 1). Survival averaged $81 \%$

Table 1. Significance of site and treatment on survival, average root collar diameter (RCD, cm), average height $(\mathrm{Ht}, \mathrm{m})$, and stand volume of crop trees [SV, $\mathrm{m}^{3} / \mathrm{ha}$ ]

\begin{tabular}{lrrrrr}
\hline Source $^{\mathrm{a}}$ & Df & Survival & RCD & Ht & \multicolumn{1}{c}{ SV } \\
\hline Jackpine & & & & & \\
$S_{i}$ & 1 & $<0.001$ & $<0.001$ & 0.004 & $<0.001$ \\
$T_{j}$ & 5 & 0.627 & 0.002 & 0.968 & 0.049 \\
$\varepsilon_{k(i j)}$ & 29 & & & & \\
\multicolumn{1}{ll}{ Black spruce } & & & & \\
$S_{i}$ & 1 & 0.037 & $<0.001$ & $<0.001$ & $<0.001$ \\
$T_{j}$ & 5 & 0.824 & $<0.001$ & 0.034 & 0.028 \\
$\varepsilon_{k(i j)}$ & 29 & & & & \\
White spruce & & & & \\
$S_{i}$ & 1 & 0.373 & 0.094 & 0.023 & 0.075 \\
$T_{j}$ & 5 & 0.405 & 0.016 & 0.091 & 0.019 \\
$\varepsilon_{k(i j)}$ & 29 & & & & \\
\hline
\end{tabular}

${ }^{\mathrm{a}} \mathrm{S}_{\mathrm{i}}=$ site $(i=1,2), \mathrm{T}_{\mathrm{j}}=$ glyphosate treatment $(j=1,2,3,4,5,6)$. 
across sites, species and treatments in the tenth growing season. At the end of tenth growing season, survival was $76 \%$ and $92 \%$ for jack pine, $79 \%$ and $90 \%$ for black spruce, and $72 \%$ and $76 \%$ for white spruce at Goose Lake and Root Lake, respectively.

Glyphosate applications significantly affected the RCDs for all three species (Table 1; Fig. 1), but the significant differences only occurred between controlled and treated plots while timing of glyphosate application between Yr 1 and Yr 5 resulted in similar RCDs (Fig. 1). Average root collar diameters (RCD) in the tenth growing season were 5.0, 2.6, and 2.3 $\mathrm{cm}$ for jack pine, black spruce and white spruce, respectively.

Height did not differ significantly with treatment for jack pine, but did significantly for black spruce $(P=0.034)$ and marginally for white spruce $(P=0.091)$ (Table 1 ; Fig. 2). Similar to RCD, the significant differences only occurred between controlled and treated plots while timing of glyphosate application between Yr 1 and Yr 5 resulted in similar heights (Fig. 2). Average heights of surviving seedlings in the tenth growing season were $2.39,1.29$, and $0.94, \mathrm{~m}$ for jack pine, black spruce, and white spruce, respectively (Fig. 2).
Glyphosate treatments significantly increased stand volume of crop trees (Table 1; Fig. 3). Similar to RCD and height growth, timing of glyphosate application between Yr. 1 and Yr. 5 did not lead to significantly differences in stand volume. In the tenth growing season, stand volume was 3.0, 0.9 and $0.5 \mathrm{~m}^{3} \mathrm{ha}^{-1}$ for jack pine black spruce, and white spruce, respectively (Fig. 3).

\section{Vegetation responses}

Vegetation cover was higher at Goose Lake than Root Lake at the beginning of the study and remained higher throughout the study period (Fig. 4). This vegetation was well established prior to implementing the treatments. Average total cover was 66\% and 29\% at Goose Lake and Root Lake, respectively, in 1990. In subsequent years, the average total cover continued to increase in control plots and reached a maximum of $146 \%$ and $83 \%$ at Goose Lake and Root Lake, respectively, in the eighth year of the study. In treated plots, total vegetation cover decreased the year after treatment and sharply increased typically to pre-treatment levels within a year to three years posttreatment (Fig. 4).

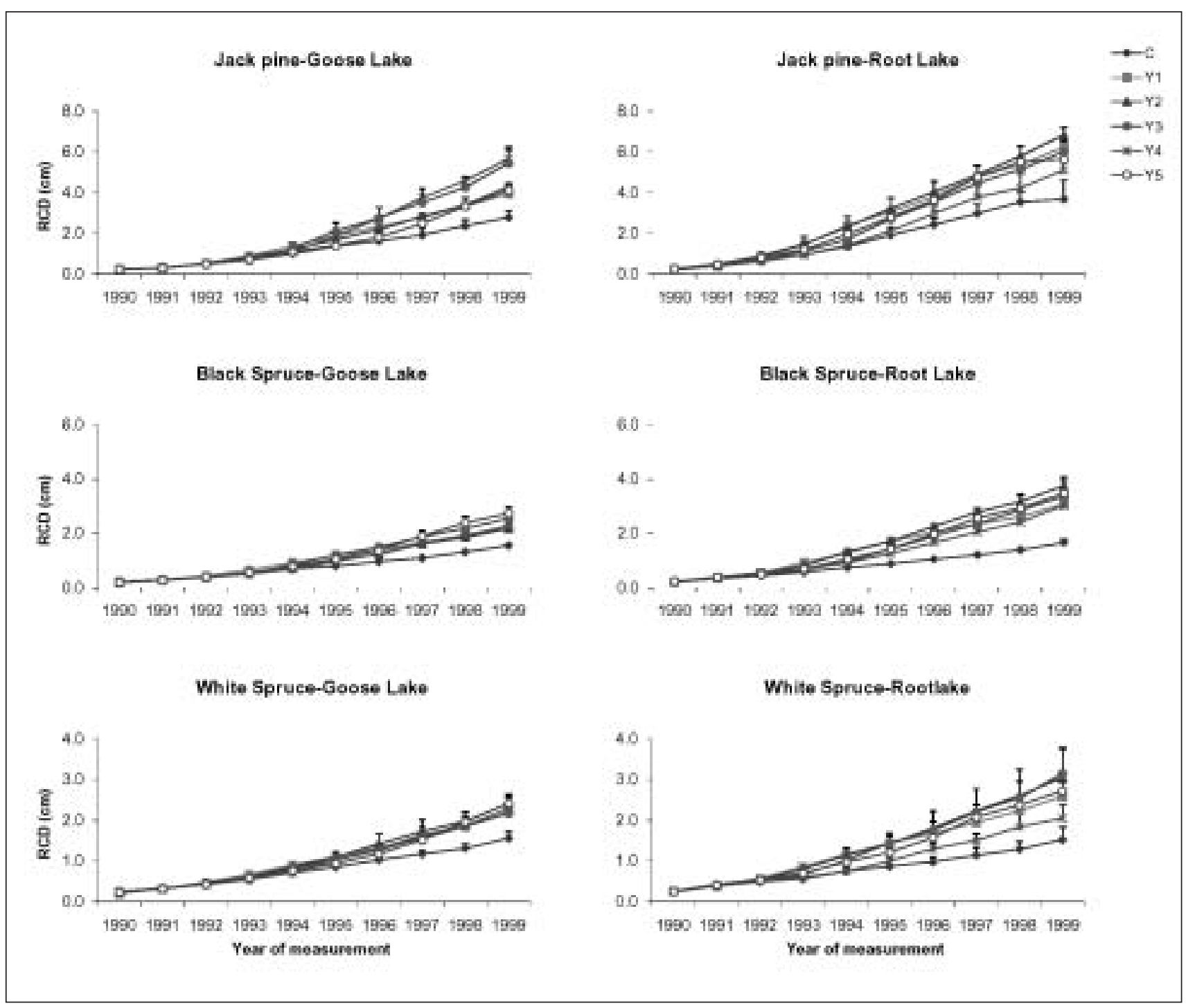

Fig. 1. Effects of glyphosate application $C C=$ no treatment, $Y 1=$ release first year after planting, $Y 2=$ release second year after planting, and so on) on root collar diameter (RCD) of three conifer species at two study sites in northern Manitoba. Error bars are 1 SE. 
Although the composition of the post-treatment vegetation differed from the controls, the glyphosate applications in Yr 1 and 5 did not reduce broadleaf cover in the same manner as applications in Yr 2 and 3 (Fig. 4). In general, shrub and hardwood cover was substantially reduced by glyphosate treatments while forb cover increased and grass and fern cover remained relatively unaffected (Fig. 4).

\section{Stand volume and weed cover}

Stepwise regression analysis showed that percent cover of grass was the most important variable that negatively affected stand volume of crop trees for all study species (Table 2). The coefficient of determination $\left(\mathrm{R}^{2}\right)$ of the fitted regressions varied with species with the highest for jack pine $\left(\mathrm{R}^{2}=0.625\right.$, MSE $=0.733)$ and lowest for white spruce $\left(R^{2}=0.325\right.$, MSE $=0.040$ ).

For two-variable models, the first variable was the same (grass cover) for all species, but the second variable differed by species. Percent cover of tall shrub, percent cover of forbs, and percent cover $\times$ height of tall shrubs were the second variables in two-variable models for jack pine, black spruce, and white spruce, respectively. The coefficient corresponding to the second variable was negative for jack pine and black spruce and positive for white spruce (Table 2).

With more than two variables, the independent variables that entered during the stepwise regressions were not consistent across species. The order of regressor variables in the model also changed in the stepwise regression as a result of multi-collinearity among independent variables.

\section{Discussion}

We observed that aerial application of glyphosate did not improve $10^{\text {th }}$-year survival of crop trees of jack pine, black spruce, or white spruce. Our finding is consistent with previous vegetation control studies (e.g., Bell et al. 2000, Fu et al. 2007). The trade-off between reduced competition and exposure to suddenly increased radiation and greater variation in temperature and humidity may explain insignificant effects of vegetation control on crop tree survival. Alternatively, increased growth resulting from less competition may lead to less defensive investments and consequently, to lower survival rates. For shade-tolerant tree species, survival is generally

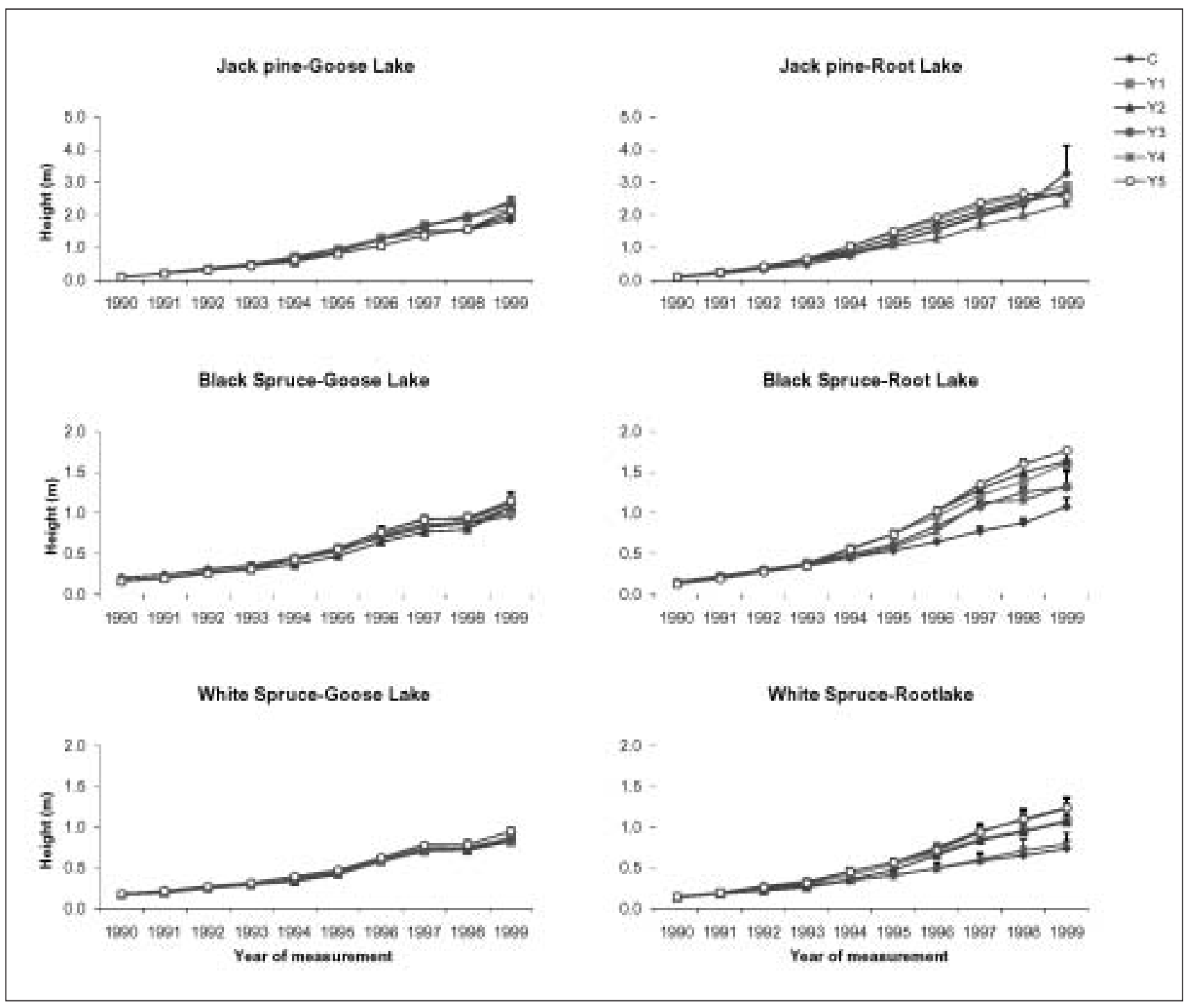

Fig. 2. Effects of glyphosate application $C C=$ no treatment, $Y 1=$ release first year after planting, $Y 2=$ release second year after planting, and so on) on stem height of three conifer species at two study sites in northern Manitoba. Error bars are 1 SE. 


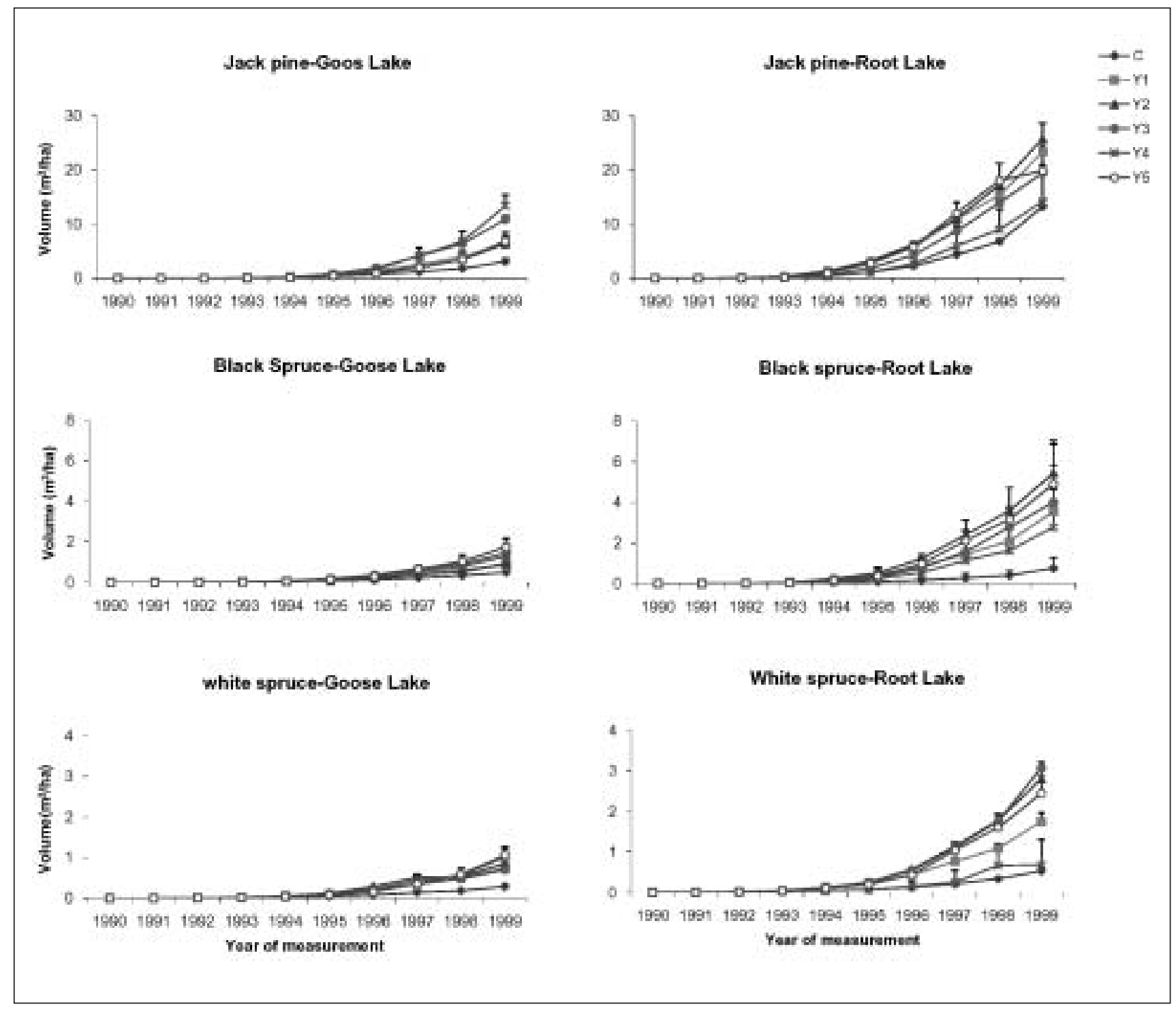

Fig. 3. Effects of glyphosate application $C C=$ no treatment, $Y 1=$ release first year after planting, $Y 2=$ release second year after planting, and so onj on stand volume of three conifer species at two study sites in northern Manitoba. Error bars are 1 SE.

independent of resource limitation from competition (Sipe and Bazzaz 1995, Chen 1997, Chen and Klinka 1998).

Glyphosate application increased crop tree RCD and stand volumes. Our findings from the northern boreal plantations are consistent with previous studies from southern boreal plantations (e.g., Chen et al. 2006, Fu et al. 2007). Compared with diameter growth, height growth of conifers is much less responsive to vegetation control (Morris et al. 1990, Brand 1991, Chen et al. 2006). The different responses between height and root collar diameter to brush control in jack pine and white spruce suggest that carbon allocation differs with level of competition (Chen et al. 1996).

Timing of glyphosate applications between years 1 to 5 had similar effects on crop tree growth. This suggests that delay in glyphosate applications within the first five years of plantation establishment would not have a negative effect on crop trees in the northern boreal forest. We explain the differences between our findings and those of Wagner et al. (1999) and Wagner and Robinson (2006) with (1) the use of repeated glyphosate applications, and (2) the composition of the competitive vegetation complex. Competition effects differ greatly between herbaceous plants and woody species (Bell et al. 2000, Willoughby et al. 2006) as the latter have more pronounced long-term effects. Recent experiments from across North America suggest that woody vegetation alone captures about $20 \%$ to $30 \%$ of the early volume growth potential of crop trees. Achieving the remaining 70\% to $80 \%$ of the growth potential of a site requires effective control of herbaceous vegetation (Wagner 2000). To maximize the growth of young conifer plantations, it may be necessary to reduce cover of grasses and forbs below a threshold of approximately $20 \%$ during the early years of plantation development (Wagner 2000). In our study, the treatments did not maintain competition below this threshold for more than a single growing season (Fig. 4). The fact that grass cover was the primary factor reducing conifer growth suggests that grasses need to be more aggressively controlled with more than a single application of glyphosate. Multiple applications, 
Root Lake
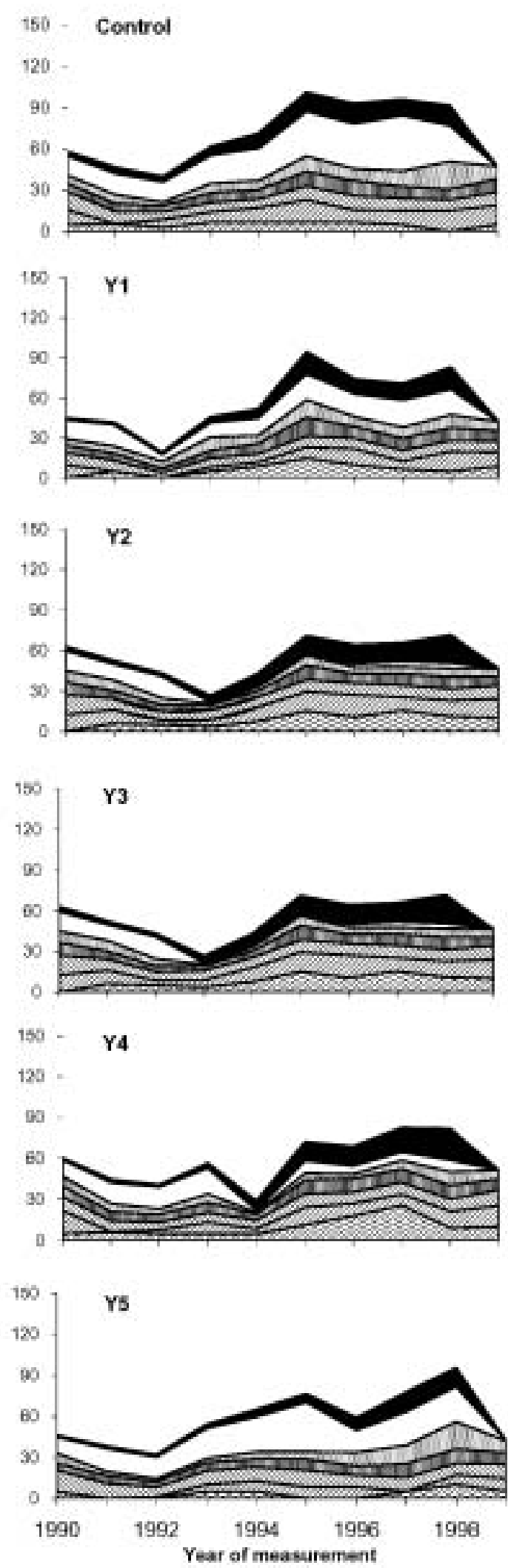

\section{Goose Lake}
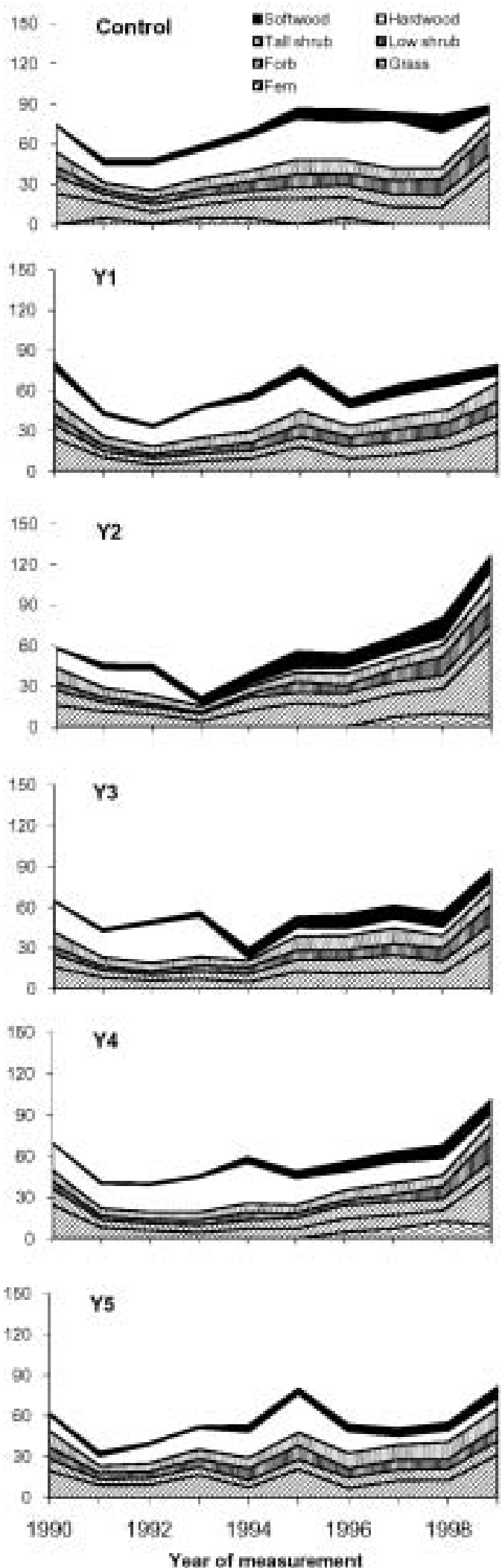

Fig. 4. Effects of glyphosate application $C C=$ no treatment, $Y 1=$ release first year after planting, $Y 2=$ release second year after planting, and so on] on competitive vegetation at two study sites in northern Manitoba. 
Table 2. Estimated coefficients and fit characteristics for one and two variable[s] models for jack pine, black spruce, and white spruce stand volume of crop trees (one variable model is: Stand voloume $=a_{0}+a_{1} x$ and two variable model is: Stand voloume $=a_{0}+a_{1} x+a_{2} y$ where $x$ and $y$ are first and second regressor variables, respectively].

\begin{tabular}{|c|c|c|c|c|c|c|}
\hline Species & Variables & $a_{0}$ & $a_{1}$ & $a_{2}$ & $\mathrm{R}^{2}$ & MSE \\
\hline \multirow[t]{2}{*}{ Jack pine } & Grass & 4.5956 & -0.1953 & - & 0.625 & 0.733 \\
\hline & Grass, tall shrub & 4.8931 & -0.1492 & -0.1210 & 0.777 & 0.456 \\
\hline \multirow[t]{2}{*}{ Black spruce } & Grass & 1.4214 & -0.0748 & - & 0.483 & 0.163 \\
\hline & Grass, forb & 1.9114 & -0.0590 & -0.0204 & 0.605 & 0.1316 \\
\hline \multirow[t]{2}{*}{ White spruce } & Grass & 0.6897 & -0.0272 & - & 0.325 & 0.0404 \\
\hline & Grass, TSh $¥$ TSc & 0.6364 & -0.0328 & 0.0298 & 0.4388 & 0.0357 \\
\hline
\end{tabular}

Note: TSh and TSc are height and cover of tall shrubs, respectively. All other variables are percent covers.

as recommended by Wagner and Robinson (2006) for control of vegetation on coarse sandy soils, may have been necessary on richer clay soils for maximum conifer growth potential to be expressed.

\section{Conclusions}

We described the effect of the timing of glyphosate application on survival and growth of jack pine, black spruce, and white spruce in the northern boreal forest. Glyphosate application did not affect survival, but increased root collar diameter and stand volume of crop trees for all the studied species. The effect of glyphosate application on height growth varied among species. The timing of glyphosate application between year 1 and year 5 did not result in a significant difference in crop tree growth. On these site conditions, a single application of glyphosate provided only temporary reductions in competition and did not reduce competition levels below the threshold needed to maximize conifer growth. Repeated glyphosate applications, as shown by Wagner and Robinson (2006), are probably necessary if the objective is to maximize conifer growth. Further research, including a follow-up measurement of this study at age 20 or later, is recommended to determine long-term effects of glyphosate treatments on boreal crop tree growth in the northern boreal forest.

\section{Acknowledgements}

We thank Manitoba Conservation and Repap Manitoba for establishing and continuously measuring the field trial and Monsanto Canada Inc. for contributing the herbicide. We also recognize the contributions of a number of individuals including Reg Hiebert, Bill Towill and Jeff Hallworth for input at the planning stages of the trial; Gupreet Singh and Glynn Edgar for developing data collection programs. We are grateful for funding provided by the Ontario Forestry Futures Trust through the Enhanced Forest Productivity Science Program. The senior author also thanks the Ministry of Education of China for an overseas scholarship.

\section{References}

Balandier, P., C. Collet, J.H. Miller, P.E. Reynolds and S.M. Zedaker. 2006. Designing forest vegetation management strategies based on the mechanisms and dynamics of crop tree competition by neighbouring vegetation. Forestry 79:3-27.

Bell, F.W., R.A. Lautenschlager, R.G. Wagner, D.G. Pitt, J.W. Hawkins and K.R. Ride. 1997. Motor-manual, mechanical, and her- bicide release affect early successional vegetation in northwestern Ontario. The Forestry Chronicle 73: 61-68.

Bell, F.W., M.T. Ter-Mikaelian and R.G. Wagner. 2000. Relative competitiveness of nine early-successional boreal forest species associated with planted jack pine and black spruce seedlings. Canadian Journal of Forest Research 30: 790-800.

Brand, D.G. 1991. The establishment of boreal and sub-boreal conifer plantations - An integrated analysis of environmental-conditions and seedling growth. Forest Science 37: 68-100.

Chen, H.Y.H. 1997. Interspecific responses of planted seedlings to light availability in interior British Columbia: survival, growth, allometric patterns, and specific leaf area. Canadian Journal of Forest Research 27: 1383-1393.

Chen, H.Y.H., W.J. Byman and F.W. Bell. 2006. Chemical site preparation influences productivity, composition, and structure of boreal mixedwoods in Ontario, Canada. Forest Ecology and Management 229: 145-154.

Chen, H.Y.H. and K. Klinka. 1998. Survival, growth, and allometry of planted Larix occidentalis seedlings in relation to light availability. Forest Ecology and Management 106: 169-179.

Chen, H.Y.H., K. Klinka and G.J. Kayahara. 1996. Effects of light on growth, crown architecture, and specific leaf area for naturally established Pinus contorta var. latifolia and Pseudotsuga menziesii var. glauca saplings. Canadian Journal of Forest Research 26: 1149-1157. Delaney J.R. 1992. Northern Manitoba field trial of Vision for plantation release establishment report. Manitoba Forestry Branch, Silviculture Section, Winnipeg, MB.

Environment Canada. 2005. Canadian Climate Normals 1971-2000 [online]. Available at http://climate.weatheroffice.ec.gc.ca/climate_ normals/index_e.html [Accessed on February 2, 2007].

Fu, S.L., F.W. Bell and H.Y.H. Chen. 2007. Long-term effects of intensive silvicultural practices on productivity, composition, and structure of northern temperate and boreal plantations in Ontario, Canada. Forest Ecology and Management 241: 115-126.

Hicks, C.R. 1993. Fundamental Concepts in the Design of Experiments. Saunders College Publishing, New York, NY.

Morris, D.M., G.B. Macdonald and K.M. McClain. 1990. Evaluation of morphological attributes as response variables to perennial competition for 4-year-old black spruce and jack pine seedlings. Canadian Journal of Forest Research 20: 1696-1703.

Munson, A.D., H.A. Margolis and D.G. Brand. 1993. Intensive silvicultural treatment - impacts on soil fertility and planted conifer response. Soil Science Society of America Journal 57: 246-255.

Munson, A.D., H.A. Margolis and D.G. Brand. 1995. Seasonal nutrient dynamics in white pine and white spruce in response to environmental manipulation. Tree Physiology 15: 141-149.

Neter, J., M.H. Kutner, C.J. Nachtsheim and W. Wasserman. 1996. Applied Linear Statistical Models., 4th edition. Richard D. Irwin, Inc., New York, NY. 
Pitt, D.G., R.G. Wagner and W.D. Towill. 2004. Ten years of vegetation succession following ground-applied release treatments in young black spruce plantations. Northern Journal of Applied Forestry 21: 123-134.

Rowe, J.S. 1972. Forest Regions of Canada. Publication No. 1300. Canadian Forestry Service, Ottawa, Ontario.

Sims, R.A., W.D. Towill, K.A. Baldwin, P. Uhlig and G.M. Wickware. 1997. Field Guide to the Forest Ecosystem Classification for Northwestern Ontario. Ontario Ministry of Natural Resources, Northwest Sci. and Technol., Queen's Printer for Ontario, Thunder Bay, ON.

Sipe, T.W. and F.A. Bazzaz. 1995. Gap partitioning among maples (Acer) in central New England: survival and growth. Ecology 76: 1587-1602.

Sutherland, B. and F.F. Foreman. 2000. Black spruce and vegetation response to chemical and mechanical site preparation on a boreal mixedwood site. Canadian Journal of Forest Research 30: 1561-1570. Thompson, D.G. and D.G. Pitt. 2003. A review of Canadian forest vegetation management research and practice. Annals of Forest Science 60: 559-572.
Wagner, R.G. 2000. Competition and critical-period thresholds for vegetation management decisions in young conifer stands. The Forestry Chronicle 76: 961-968.

Wagner, R.G., K.M. Little, B. Richardson and K. McNabb. 2006. The role of vegetation management for enhancing productivity of the world's forests. Forestry 79: 57-79.

Wagner, R.G., G.H. Mohammed and T.L. Noland. 1999. Critical period of interspecific competition for northern conifers associated with herbaceous vegetation. Canadian Journal of Forest Research 29: 890-897.

Wagner, R.G. and A.P. Robinson. 2006. Critical period of interspecific competition for four northern conifers: 10-year growth response and associated vegetation dynamics. Canadian Journal of Forest Research 36: 2474-2485.

Walstad, J.D. and P.J. Kuch. 1987. Forest Vegetation Management for Conifer Production. John Wiley and Sons, New York, NY.

Willoughby, I., D.V. Clay and F.L. Dixon. 2006. The effect of competition from different weed species on the growth of Betula pendula seedlings. Canadian Journal of Forest Research 36: 1900-1912. 